\title{
Scientific Study: Enhancing Baby's Body Immunity Through the Javanese Tahnik Tradition
}

\author{
Elfrida Nurutstsany ${ }^{*}$, Hersy Fujiyanti** \\ Biology Education Department, Faculty of Science and Technology, UIN Walisongo Semarang \\ Jl. Prof. Dr. Hamka No 3-5 Semarang 5018, Central Java, Indonesia. Telp/Fax: (024) 7604554, 7624332/(024) 7601293 \\ Email: elfridatsany@gmail.com*, fujiyantihersy@gmail.com**
}

\begin{abstract}
Existence of Javanese culture is still inherent in modern times with beliefs that cannot be abandoned. Tradition nyetaki is an expression of gratitude to God about the birth of a child. Based on the view of Islam, it is called tahnik, which is to chew dates until smooth and then put into the baby's mouth and rub it into the palate so that there are some dates that are swallowed. In addition to dates, foods that are commonly used are sweet foods. Tahnik is done by people who are considered experts in religious science or have a high spiritual spirit. In the basics saliva and mouth store various kinds of bacteria. The phenomenon that occurs due to the tradition of tahnik is to strengthen the baby's immunity. The research method is descriptive explorative qualitative. Data and sources are obtained through observation to the community and literacy studies from various valid reference sources. This study examines the local wisdom that is trusted by the people of Java about Islamic immunization. Cultural know-how involves dental peristalsis, oral amylase enzymes, and bacteria in the mouth. Positive bacteria in the tahnik process will move to the baby's stomach so as to stimulate natural immunity. The bacteria contained in the mouth will make the natural immune system, so the body is resistant to these bacteria. The mouth contains an amylase enzyme that can break down glucose. Baby's glucose needs are less than $20 \mathrm{mg} / 100 \mathrm{~mL}-30 \mathrm{mg} / 100 \mathrm{~mL}$ of blood so that they are susceptible to contracting the disease. So, dates or sweet foods that contain carbohydrates break down into simple molecules and speed up the digestive process. The spiritual value of the power of prayer and public trust strengthens the baby's immune system.
\end{abstract}

Keywords: Body imunity, Scientific study, Tahnik

\section{INTRODUCTION}

The habit of people in ancient times that was continuously carried out from generation to generation was the ancestral culture that we need to preserve to maintain the existence of a nation that is rich in culture. Like Javanese society that is inseparable from a tradition or culture carried out by its ancestors in ancient times. One of them is the tahnik culture. Tahnik was chewing dates and rubbing them into the palate of the baby's mouth. It should be done after the birth which aims to train the baby to eat and strengthen himself (Sulayman, 2018).

This habit is often carried out by Central Java people who are doing the tradition of being chewed which is chewing dates until smooth which is then inserted into the baby's mouth and rubbing it into the palate so that there are some dates that are swallowed. Which in Islam or the sunnah of the apostle is called the tahnik. Abû Musa alasy'ari used to have a son then he brought the baby boy to the apostle, he then gave him the name Ibrahim, usually with dates and prayed for him with blessing. Asmâ bint Abi Bakr when giving birth' Abdullāh ibn Zubair, he told of taking his baby before the Prophet and being put in his cradle. Then he asked for a date, chewed it then spit it into the baby's mouth, so that the first time he entered his oral cavity was the Prophet's saliva. Then he worked it out with dates and prayed for it and blessed it (Sulayman, 2018).

Society considers that the tahnik tradition is to strengthen the baby's immunity. Whereas in the medical world states that in the basics of saliva and mouth store various types of bacteria. In the oral cavity various types of bacteria can be found, including Streptococcus, Lactobacillus, Staphylococcus, and Corynobacteria, as well as other types of anaerobic bacteria such as Bacteroides. The bacteria can be commensal, but if the condition of the oral cavity is beneficial for the development of bacteria, the number of bacteria will increase, which triggers the occurrence of disease in the oral cavity (Karim, 2015).

Saliva is an exocrine secretion fluid in the mouth that is in contact with the mucosa and teeth, originating mainly from three pairs of major salivary glands, minor salivary glands in the oral mucosa (Kasuma, 2015). But people also believe that bacteria found in the mouth will make the immune system natural, so the body is resistant to these bacteria. In addition, the community also believes that children who are taught and prayed by knowledgeable people will add to the kindness of the child. Because prayer is the biggest factor of success in educating children. In Islam, tahnik is likened to an immunization that cannot be separated from the teachings of Islam. Tahnik has been carried out from the time of the apostles and until now. This culture continues until now and becomes local wisdom in certain areas.

Tahnik must be done by people who are knowledgeable like the prophet Muhammad because they are considered to be blessed by him. So that until now tahnik must be done by people who have high knowledge. The spiritual value of the power of public 
prayer and trust strengthens the baby's immune system. Tahnik uses dates or sweets like honey. Because the content in dates is very good for the health of the baby. The baby's glucose needs are less than $20 \mathrm{mg} / 100 \mathrm{ml}$ $30 \mathrm{mg} / 100 \mathrm{ml}$ of blood so they are susceptible to contracting the disease. So, dates or sweet foods that contain carbohydrates break down into simple molecules and speed up the digestive process. So tahnik is recommended to use sweets. In addition to believing in increasing the baby's immune system, this tahnik tradition is also carried out as gratitude to God almighty for the birth of a child.

\section{MATERIALS AND METHODS}

\section{Study Area}

Technique data colllection in this research is through a method of study literasi (library research). Researchers collect various data between immunity the body of a baby through the process tahnik with of infants that did not through a process tahnik. Researcher compares the immunity the body a baby supported by scientific research invalid. Data sources obtained from book, journal, articles, the results of the study and online library.

\section{Data Analysis}

The data which has been collected writer, so the next step is to analyze the data. Researchers used data analysis technique qualitative research was conducted with the approach descriptive analytical. According to Sugiono (2009:29) the method of descriptive serves to described or give a sense of object is as high as through data or by samples that were collected. Researchers give a description of the realities of the influence of the process of tahnik against immunity the body of a baby. Just as there is trouble taken the time when the research carried out. After that, it is processed and analyzed the result of the study to be taken conclusion.

\section{RESULTS AND DISCUSSION}

\section{Baby's Body Immunity with Tahnik}

The process of tahnik undertaken in the hope guard and protect a baby to avoid various kinds of diseases. Immunity system that is formed from the process of tahnik involving white blood cells (lymphocytes). The process of tahnik diffusing specifically and nonspecific. Specific immunity by activating antibodies and lymphocytes. Bacteria carried by the saliva will be effective do the introduction of an antigen and the attack. While when through antibodies to enable the effectiveness of opsonization, complement activity, antibody-mechanism dependent cell-mediated cytotoxicity. An antigen in the form of a virus or bacterium the kill an antigen in the form of a virus or bacterium which is found in the fluid of the body. In addition, an antigen in the form of a virus or bacterium can be recognized with the formation of memory. When memory cells had been formed there shall not be any sustainable infection. Hence a system of immunity can be increased.

\section{Islamic Immunization}

Islamic give peace and special attention to every one. Rasulullah says he has taught Muslims procedures for healthcare since born originating from God. All kinds of processes destined to the world wisdom, including tahnik tradition. The clergy agreed made way as a law tahnik for the newborn. This unique believed to the process tahnik is culprit people who are knowledgeable who were having kinship and close to God. An intermediary could ask do praying and blessing.

Tahnik is a way of health care physically introduced when the messenger by granting palm are chewed or avocado in the mouth baby's and pray. Religious value to the process tahnik very attached. The blessings are fixed and increase well after implemented tahnik tradition.

Immunisation is the procedure to elevate in the degree of body immunity by inducing response memory there are sick or on certain or pathogen. Basically of a newborn infant having inborn or natural immunity. Natural immunity in the form of an antibody that derived from the placenta and colostrum mother. In addition, immunization can be derived from natural infection outside the body that can stimulate an immune response and a cell memory (Baratawijaya, 2009). Spirituality intervention is a concept of Islam that became the basis of healing components. Prayer is foundation of the reading Holy Qur'an, the event or revealing to God, fasting, give alms and run sunnah when it came to being an attempt tawakal and ikhtiar to god. Of the business which performed by human beings must be conducted in a balance between this world and the next.

Spirituality interventions comprise providing facilities, patient preparations, prayer, collaboration with family, and nursing intervention based on Islamic tenets. Nurse usually collaborates with patient, family, and religion to care for patients. Spirituality intervention refers to nursing intervention based on Islamic tenets including original Islamic methods; prayer, recitation of the Qur'an, zikr, fasting, charity, Prophet's methods, and modified Islamic methods to balance and harmonize body mind spirit of patients (Bahar, 2005).

\section{Scientific Study of Tahnik}

The purpose of tahnik does not mean that feed infant, but only rubbing food to the mouth baby. But food for infants is a colostrum, namely breastfeeding the first time out. A sunnah for parents who just birth to perform tahnik. Palm and smeared chewed a baby mouth. The use of palm can be replaced by foodstuff sweet. Every child newborn have potential to death when lack of sugar in blood or the temperature of a body like as where has cold. Composition glucose in 
the blood newborns very little. The glucose in the blood baby is directly proportional to weight. The small size weight baby, then sekamin little glucose it. Premature babies weight $2,5 \mathrm{~kg}$ and sugar content $20 \mathrm{mg} / 100 \mathrm{ml}$ (Al-Shabib, 2003).

Based on the palm trees including a greater sin in the kind of fruit shahih worth explaining that palm trees constitute the food of that which is feasible for consumption as stock daily food. Phoenix dectylifera, therefore, is one kind of palm (Araceae) sweet with a flavor. Was in the area wilderness habitats of palm trees. Palm trees containing salicylic acid works as anti the clotting of blood, anti-inflammatory, and remove the pain. The womb potassium serves as stability the beats of the heart, blood pressure, and prevent the disease a stroke. A fiber which is contained in fruit of the date palm good for the gastrointestinal tract as prevent constipation and easing defecate. Calcium, phosphorus, and magnesium that is added to its palm trees can help bone growth and health bone and of teeth.

Varopus kinds of the womb of nutrition in date palm were dry to justify that the palm trees advisable to be consumed. Based on the point of view of science, could be clearly seen composition nutrients. The womb sugar on palm trees consists of fructose, glucose, sucrose, in the form of polysaccharides and starch and cellulose. So date palm was dry one of food that is easy to digest by metabolism of the body do that bodies faster absorb and guy get energy (Soebahar, 2015).

The inversion of spiritual in the process of tahnik containing $5 \%$ glucose. The benefit of tahnik baby is for reducing pain during the delivery process. An enzyme digestion on tahnik palm trees will help change the content of those compounds in palm trees so that it can be more easily digestible and absorbs by the body of baby. The saliva function in the cud palm trees is reactor. A process of mastication in the mouth, polysaccharide content in the form of starch and cellulose in palm will be broken down by an enzyme an amylase (ptyalin) that was found in the saliva be maltose. Maltose is sugar simple (of disaccharides which is most easily digestible and absorbed by the body of a baby. Nutrition simple on palm trees suitable to digest by infants that a system has not yet been formed with perfect digestive.

The primary locations of the tahnik process were in the mouth. In general, in the mouth, there are more than 900 a species of bacterium that 280 species of them successfully identified and named (Dewhirst, 2010). There are in the mouth of microbes which are commonly called an oral to be microflora. A process of mastication of palm trees indirectly brings oral bacteria on the material to be microflora and the results of the cud palm trees. The provision of the cud dates to be microflora bacteria containing an oral can target stimulates an immune response. Response of the immune system against bacteria to be microflora oral as an antigen until the establishment of the upcoming memory cells by the immune system.

Nutrition contained in palm being a medium growth good for organisms. Cud dates to the process tahnik being a medium growth good for oral microflora mixed in palm cud. Cud dates to the process tahnik provide the introduction of antigens for the immune system target. Antigens of viruses or bacteria has recognized eat be eliminated from inside the body. Memory cells they kind of bacteria or viruses give impact on system immunity that there would be sustainable infection. Hence the process tahnik able to improve immunity, especially newborn babies.

\section{CONCLUSIONS}

Tahnik can improve the immune system body of baby through their lymphocyte bacteria. An antigen in the form of a virus or bacterium will record by memory so that recognizable. When that is not gonna happen sustainable infection the immune system so that the body of a baby increased.

\section{REFERENCES}

Al-Shabib, W, et al. 2003. The Fruit of The Date Palm: Its Possible Use as The Best Food for The Future?. International Journal of Food Sciences and Nutrition. Volume 54 (4) : 247-259.

As-Sulayman, Syaikh Abdussalam. 2018. Panduan Mendidik Anak sesuai Sunah Nabi. Depok : Anak Teladan.

Bahar, Z, et al. 2005. The Effects of Islam and Traditional Practices on Women's Health and Reproduction. Nursing Ethics. Volume 12 (6) : 468-474.

Baratawidjaja, K.A dan Iris Renggaris. 2009. Imunologi Dasar. Jakarta : Balai Penerbit FKUI.

Dewhirst, F.E et al. 2010. The Human Oral Microbiome. Journal of Bacteriology. Volume 192 (19) : 5002-5017.

Karim, Punggawa Gauk. 2015. Perbedaan Jumlah Koloni Bakteri dalam Saliva sebelum dan setelah Aplikasi Pit dan Fissure Sealant. Makasar : Universitas Hasanuddin.

Kasuma, Biomed. 2015. Fisiologi dan Patologi Saliva. Padang : Andalas University Press.

Primurdia, E.G, Kusniadi, J. 2014. Aktivitas Antioksidan Minuman Probiotik Sari Kurma (Phoenix dactilyfera L) dengan Isolat L. Plantarum dan L. Casei. Jurnal Pangan dan Agroindustri. Volume 2 (3) : 98-109.

Soebahar, Moh Erfan, et al. 2015. Mengungkap Rahasia Buah Kurma dan Zaitun dari Petunjuk Hadits dan Penjelasan Sains. Journal Ulul Albab. Volume 16 (2) : 191-214.

Sugiono.2009. Metode Penelitian Pendidikan Kualitatif, Kuantitatid, dan $R \& D$. Bandung : Alfabeta. 
THIIS PAGE INTENTIONALLY IEIT BLANK 